\title{
Effects of Continuous Pollution by Pharmaceutical Micropollutants on the Fouling of a Membrane Bioreactor Treating Domestic Wastewater
}

\section{L'impact de la pollution continue des micropolluants pharmaceutiques sur le colmatage du bioreacteur à membrane pour le traitement des eaux usées domestiques}

\author{
Chengcheng Li, Christelle Guigui et Corinne Cabassud
}

Volume 28, numéro 1, 2015

Reçu le 10 novembre 2014, accepté le 27 janvier 2015

URI : https://id.erudit.org/iderudit/1030007ar

DOI : https://doi.org/10.7202/1030007ar

Aller au sommaire du numéro

Éditeur(s)

Université du Québec - INRS-Eau, Terre et Environnement (INRS-ETE)

ISSN

1718-8598 (numérique)

Découvrir la revue

Citer cet article

Li, C., Guigui, C. \& Cabassud, C. (2015). Effects of Continuous Pollution by Pharmaceutical Micropollutants on the Fouling of a Membrane Bioreactor Treating Domestic Wastewater. Revue des sciences de l'eau / Journal of Water Science, 28(1), 51-56. https://doi.org/10.7202/1030007ar

\section{Résumé de l'article}

Les bioréacteurs à membrane (BAM) sont de plus en plus utilisés pour le traitement et la réutilisation des eaux usées domestiques et de grandes préoccupations ont été soulevées concernant certains polluants émergents traces trouvés dans l'environnement aquatique dans la dernière décennie, notamment les produits pharmaceutiques. En conséquence, l'élimination des micropolluants pharmaceutiques par BAM a été étudiée de manière considérable, mais il y a encore un manque de connaissances sur l'impact de la présence actuelle de micropolluants pharmaceutiques dans les eaux usées domestiques sur le colmatage de BAM. Parmi les différents produits pharmaceutiques, il a été décidé de se concentrer sur la carbamazépine (CBZ), un médicament antiépileptique, en raison de sa présence dans les eaux usées domestiques et de sa persistance dans les processus biologiques, y compris BAM. L'analyse chimique des produits microbiens solubles (PMS) dans le surnageant a montré que l'introduction continue de CBZ dans un BAM immergé par l'intermédiaire de l'alimentation (environ $90 \mu \mathrm{g} / \mathrm{L}$ CBZ dans l'alimentation) conduit à une augmentation significative de la concentration en protéines mais aucun changement significatif n'a été constaté pour les polysaccharides. L'analyse par HPLC-SEC a montré que l'addition de CBZ induit une augmentation significative des protéines de 10-100 kDa dans le surnageant et une légère diminution des protéines de 100-1 $000 \mathrm{kDa}$. Après addition de CBZ, une augmentation significative de la pression transmembranaire (PTM) dans le BAM a été observée, ce qui indique que l'augmentation de la quantité des protéines de 10-100 kDa a conduit à un colmatage plus grave provoqué par le colmatage interne dans le dépôt qui a été formé sur la surface de la membrane de BAM. Cette étude permet également de suggérer que les protéines de 10-100 kDa pourraient jouer un rôle majeur dans le phénomène de saut PTM. Par ailleurs, il a été constaté que l'addition de CBZ dans le BAM affecte les activités biologiques : une légère inhibition de la respiration exogène a été observée.
Ce document est protégé par la loi sur le droit d'auteur. L’utilisation des services d’Érudit (y compris la reproduction) est assujettie à sa politique d'utilisation que vous pouvez consulter en ligne.

https://apropos.erudit.org/fr/usagers/politique-dutilisation/ 


\title{
EFFECTS OF CONTINUOUS POLLUTION BY
}

\section{PHARMACEUTICAL MICROPOLLUTANTS ON THE FOULING OF A MEMBRANE BIOREACTOR TREATING DOMESTIC WASTEWATER}

\author{
L'impact de la pollution continue des micropolluants pharmaceutiques sur le colmatage du bioreacteur à membrane pour le \\ traitement des eaux usées domestiques
}

\author{
ChengCheng LI $I^{1,2,3}$, Christelle GUiGUI ${ }^{*, 2,3}$ AND Corinne CABASSUD ${ }^{1,2,3}$ \\ ${ }^{1}$ Université de Toulouse, INSA, UPS, INP, LISBP, 135, Avenue de Rangueil, 31077 Toulouse, France. \\ ${ }^{2}$ INRA, UMR792 Ingénierie des Systèmes biologiques et des Procédés, 31400 Toulouse, France. \\ ${ }^{3}$ CNRS, UMR5504, 31400 Toulouse, France.
}

Reçu le 10 novembre 2014, accepté le 27 janvier 2015

\begin{abstract}
Membrane bioreactors (MBR) are increasingly used for domestic wastewater treatment and reuse and great concerns have been raised in the last decade about some emerging trace pollutants found in aquatic environment, notably pharmaceutical products. As a consequence, the removal of pharmaceutical micropollutants by MBRs has been extensively investigated but there is still a lack of knowledge on the effects of the current presence of pharmaceutical micropollutants in domestic wastewaters on MBR fouling. Among the different pharmaceuticals, it was decided to focus on carbamazepine (CBZ), an anti-epileptic drug, because of its occurrence in domestic wastewaters and persistence in biological processes including MBRs. The chemical analysis of soluble microbial products (SMPs) in the supernatant showed that a continuous introduction of CBZ into a submerged MBR via the feed (about $90 \mu \mathrm{g} / \mathrm{L} \mathrm{CBZ}$ in the feed) led to a significant increase
\end{abstract}

in the concentration of proteins whereas no significant change was found for polysaccharides. Size exclusion high performance liquid chromatography (HPLC-SEC) analysis showed that the addition of CBZ induced a significant increase of 10-100 kDa proteins in the supernatant and a slight decrease of 100-1000 kDa proteins. After addition of CBZ a significant increase of transmembrane pressure (TMP) in the MBR was observed, which indicates that the increase of the quantity of $10-100 \mathrm{kDa}$ proteins led to a more severe fouling caused by internal fouling in the biocake that was formed on MBR membrane surface. This study also suggests that 10$100 \mathrm{kDa}$ proteins might play a major role in the TMP jump phenomenon. Moreover it was found that addition of CBZ to the MBR affected the biological activities, as a slight inhibition of the exogenous respiration rate was observed.

Key words: Membrane bioreactor, pharmaceutical micropollutants, carbamazepine, membrane fouling, proteinlike substances. 


\section{RÉSUMÉ}

Les bioréacteurs à membrane (BAM) sont de plus en plus utilisés pour le traitement et la réutilisation des eaux usées domestiques et de grandes préoccupations ont été soulevées concernant certains polluants émergents traces trouvés dans l'environnement aquatique dans la dernière décennie, notamment les produits pharmaceutiques. En conséquence, l'élimination des micropolluants pharmaceutiques par BAM a été étudiée de manière considérable, mais il y a encore un manque de connaissances sur l'impact de la présence actuelle de micropolluants pharmaceutiques dans les eaux usées domestiques sur le colmatage de BAM. Parmi les différents produits pharmaceutiques, il a été décidé de se concentrer sur la carbamazépine (CBZ), un médicament antiépileptique, en raison de sa présence dans les eaux usées domestiques et de sa persistance dans les processus biologiques, y compris BAM. Lanalyse chimique des produits microbiens solubles (PMS) dans le surnageant a montré que l'introduction continue de CBZ dans un BAM immergé par l'intermédiaire de l'alimentation (environ $90 \mu \mathrm{g} / \mathrm{L} \mathrm{CBZ}$ dans l'alimentation) conduit à une augmentation significative de la concentration en protéines mais aucun changement significatif n'a été constaté pour les polysaccharides. L'analyse par HPLC-SEC a montré que l'addition de CBZ induit une augmentation significative des protéines de 10-100 kDa dans le surnageant et une légère diminution des protéines de 100-1 000 kDa. Après addition de CBZ, une augmentation significative de la pression transmembranaire (PTM) dans le BAM a été observée, ce qui indique que l'augmentation de la quantité des protéines de 10$100 \mathrm{kDa}$ a conduit à un colmatage plus grave provoqué par le colmatage interne dans le dépôt qui a été formé sur la surface de la membrane de BAM. Cette étude permet également de suggérer que les protéines de 10-100 kDa pourraient jouer un rôle majeur dans le phénomène de saut PTM. Par ailleurs, il a été constaté que l'addition de CBZ dans le BAM affecte les activités biologiques : une légère inhibition de la respiration exogène a été observée.

\section{Mots-clés: Bioréacteur à membranes, micropolluants phar- maceutiques, carbamazépine, colmatage des membranes, protéines}

\section{INTRODUCTION}

Nowadays, water scarcity is still a big challenge facing humanity in many places around the world. To solve this problem, municipal wastewater has been considered to be an alternative water source for various applications after proper treatment. Among all kinds of treatment processes, membrane bioreactor (MBR) has been increasingly used in municipal wastewater reuse and reclamation applications due to its high effluent quality. When reclamation of the treated water is concerned, much attention has been paid to the presence of some micropollutants, notably the pharmaceuticals, in domestic wastewater due to their potential adverse effects on human health (DAUGHTON and TERNES, 1999; VERLICCHI et al., 2012). Therefore, many studies have been carried out to investigate the removal of pharmaceutical micropollutants in MBR (SIPMA et al., 2010). Also, some studies reported that the presence of pharmaceutical micropollutants in MBR could induce the release of soluble microbial products (SMPs) in MBR (LAY et al., 2012), which may significantly affect the MBR fouling. However, in the literature, very few study investigated the effects of pharmaceutical micropollutants on MBR fouling, which still remains the major limitation for MBR development.

The main objective of this study was to examine the effects of pharmaceutical micropollutants, which are frequently found in municipal wastewater, on the MBR fouling. Carbamazepine (CBZ), an anti-epileptic drug, was selected as a representative compound of pharmaceutical micropollutants in this study because it is one of the most frequently detected pharmaceutical micropollutants in municipal wastewater and it is almost not biodegraded in MBR. A lab-scale submerged MBR, using a flat sheet microfiltration membrane (Kubota, Japan), was used in this study. CBZ was continuously introduced in MBR via the feed (CBZ was added into the feed to $90 \mu \mathrm{g} / \mathrm{L}$ ). Fouling in the MBR was characterized by the transmembrane pressure (TMP). HPLC-SEC using a fluorescence detector was used to characterize protein-like SMPs in MBR. Concentrations of proteins and polysaccharides were analyzed in supernatant and permeate of MBR. Fouling propensity of activated sludge was characterized using some standardized filterability tests performed with a stirred dead-end filtration cell.

\section{MATERIAL AND METHODS}

\subsection{MBR set-up}

A lab-scale submerged MBR set-up consisting of an anoxic reactor $(5.4 \mathrm{~L})$ and an aerobic reactor $(12.6 \mathrm{~L})$ was used in this study. A flat sheet microfiltration membrane (Kubota, Japan) was submerged inside the aerobic reactor. It has an effective filtration area of $0.1 \mathrm{~m}^{2}$, with an average pore size of $0.2 \mu \mathrm{m}$. This MBR was operated at the high sludge retention time (SRT) of 30 days, with a sludge concentration in the aerobic reactor between 6-8 g/L. The instantaneous permeate flux was fixed at $15 \mathrm{~L} / \mathrm{h} / \mathrm{m}^{2}$ with filtration/relaxation cycles of $8 \mathrm{~min} / 4 \mathrm{~min}$, leading to a net permeate flux of $10 \mathrm{~L} / \mathrm{h} / \mathrm{m}^{2}$. Municipal 
astewater was taken from a wastewater treatment plant close to Toulouse, France, after primary physical treatment.

\subsection{Analytical methods}

Supernatants were prepared by centrifugation of the sludge samples at $4000 \mathrm{~g}$ during ten minutes at room temperature. High performance liquid chromatography-size exclusion chromatography (HPLC—SEC) analysis was performed by an Akta Purifer (GE Healthcare, USA), equipped with a column Protein Kw804 (Shodex, Japan), a silica-based column with an exclusion limit of $1000 \mathrm{kDa}$, and a fluorescence detector (Varian, USA). Excitation/emission wavelengths were respectively set at 280/350 nm to detect protein-like substances. Protein concentration in the supernatants, expressed as mg equivalent of bovine serum albumin per liter, was measured by the acid bicinchoninic method (SMITH et al., 1985). Polysaccharide concentration, expressed as mg equivalent of glucose per liter, was measured by the Anthrone method (DREYWOOD, 1946). The values of protein and polysaccharide concentration are the average of three repetitions.

\subsection{Filterability tests}

Filterability tests were carried out in an Amicon cell (Millipore), with an effective membrane filtration surface of about $13.4 \mathrm{~cm}^{2}$, at constant transmembrane pressures (TMP) of $0.5 \mathrm{bar}$, using $150 \mathrm{kDa}$ polyethersulfone (PES) membranes. A new membrane sample was used for each filtration test. During the filtration, the sludge was stirred at $200 \mathrm{rpm}$.

\section{RESULTS AND DISCUSSION}

\subsection{Effects of $C B Z$ on $M B R$ sludge}

\subsubsection{Effects of CBZ on biomass}

Sludge microbial activity was characterized by the exogenous respiration rate in respirometric batch experiments. A slight but not significant inhibition of microbial activity was observed (results not shown here). Also, no significant difference on floc size distribution was found after addition of CBZ in MBR (results not shown here).

\subsubsection{Effects of CBZ on supernatant}

Figure 1 shows that after addition of CBZ in MBR, a significant increase in protein SMPs in MBR supernatant was observed whereas no significant difference on the retention of protein SMPs was found, which indicated that the increased protein SMPs were mainly relatively small molecules that could pass through MBR membrane. Figure 1 also showed that several days after the addition of CBZ the protein SMPs in supernatant started to decrease until to the original level

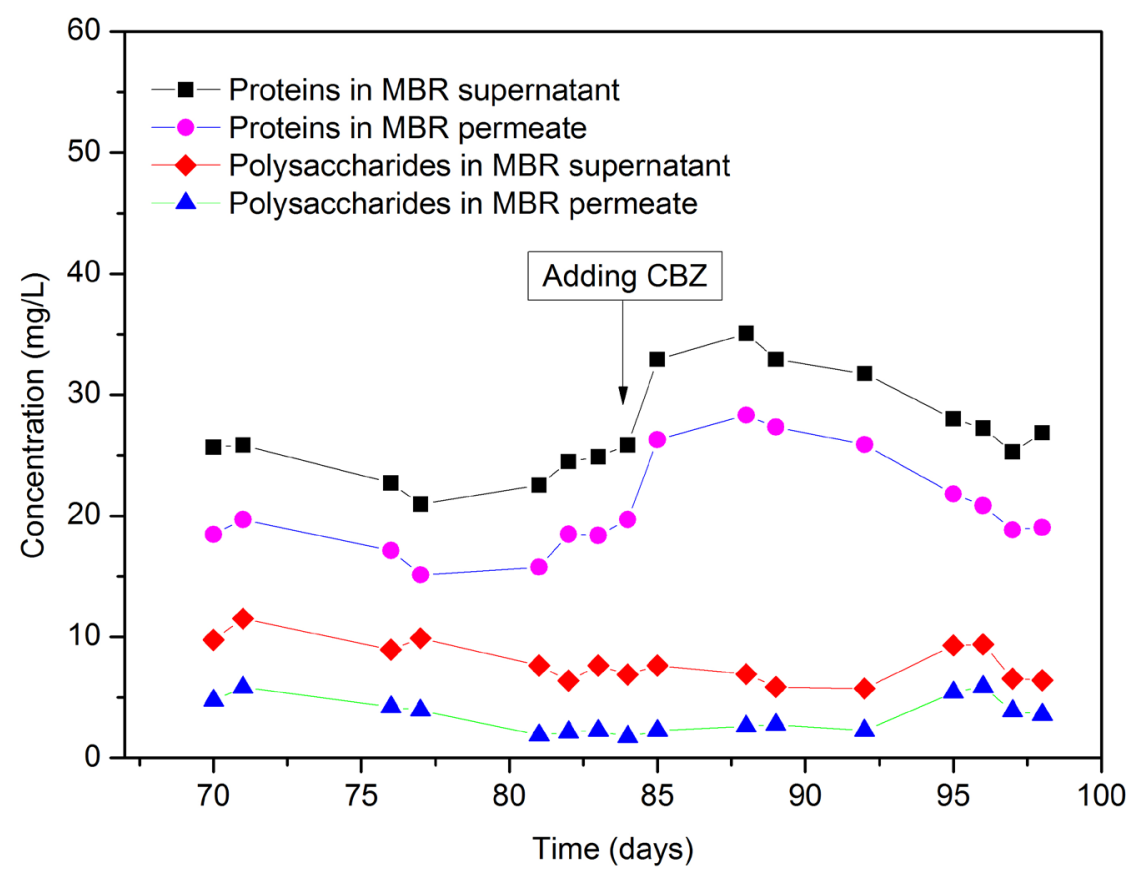

Figure 1. Effects of $\mathrm{CBZ}$ on the concentration of soluble microbial products. $L$ 'impact de CBZ sur concentration de produits microbien solubles. 


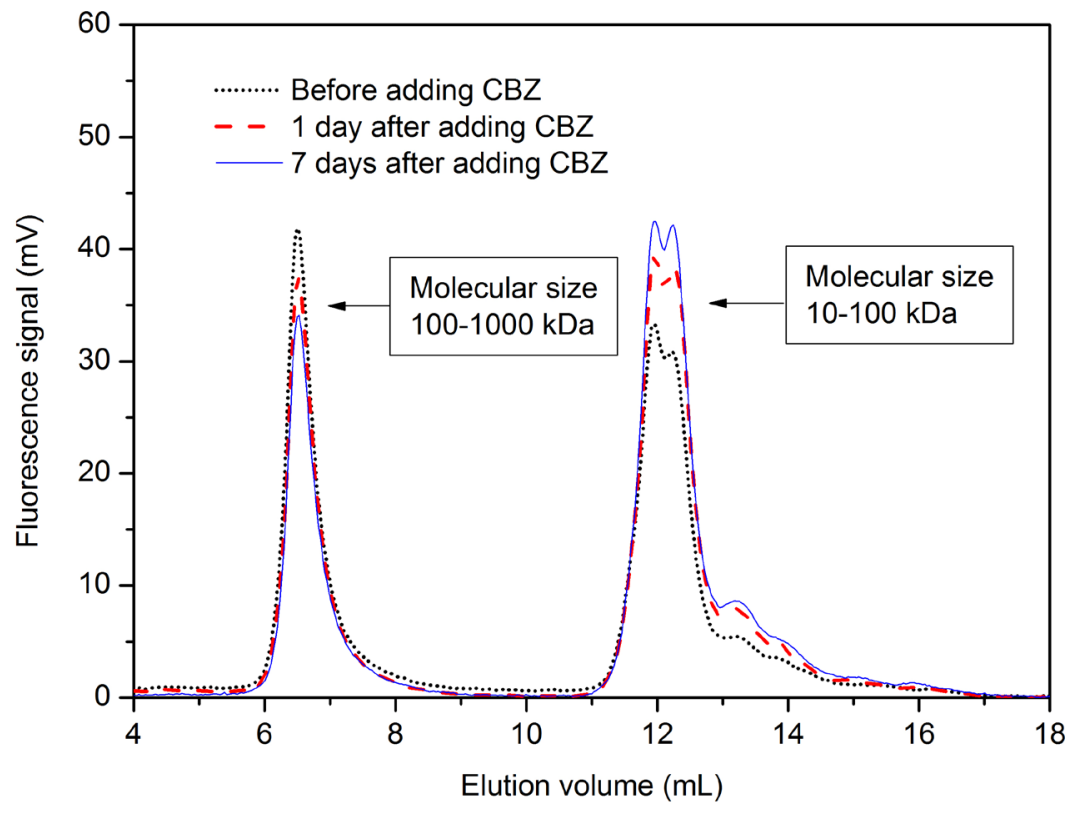

Figure 2. HPLC-SEC analysis of MBR supernatants. Analyse de HPLC-SEC sur surnageant de BAM

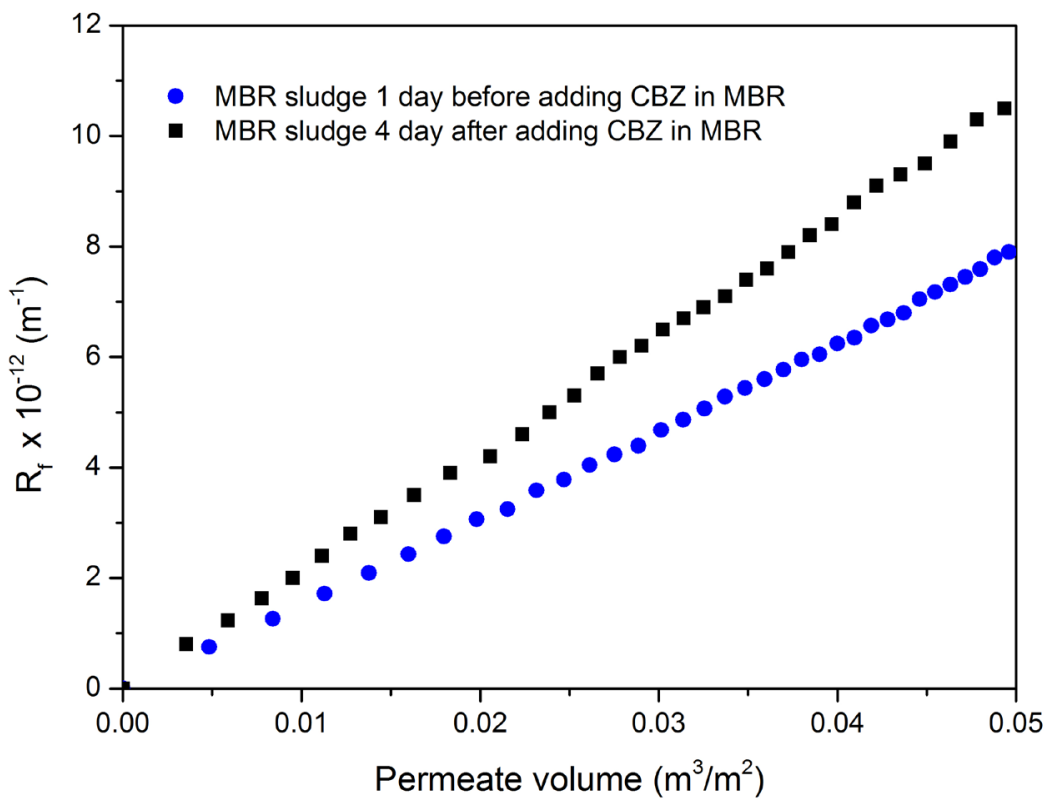

Figure 3. Filterability tests of MBR sludges on $150 \mathrm{kDa}$ polyethersulfone (PES) membranes Tests de filtration des boues de BAM sur membranes de 150 kDa polyethersulfone (PES) 
after about two weeks after the addition of CBZ, which also indicated the acclimation of biomass to CBZ stress. Moreover, no significant change in polysaccharide SMPs was found.

Figure 2 shows that the protein-like SMPs in MBR supernatant display bimodal distribution. After addition of

CBZ in MBR a decrease of 100-1 $000 \mathrm{kDa}$ protein-like SMPs was observed, which may be caused by the inhibition of sludge microbial activity; whereas a more significant increase of 10-100 kDa protein-like SMPs was found, which may be caused by the microbial response when facing pharmaceutical stress.

\subsection{Effects of CBZ on membrane fouling}

\subsubsection{Effects of $C B Z$ on fouling propensity of MBR sludge}

Figure 3 shows that the fouling propensity, expressed as the fouling resistance (Rf), of activated sludge increased after addition of CBZ in MBR, which confirmed the important role of 10-100 kDa protein-like SMPs in the biocake structure during the sludge filtration, since no significant change in biomass quality was observed.

\subsubsection{Effects of $C B Z$ on $M B R$ fouling}

Figure 4 presents the time-variation of TMP during operation of the MBR. Fourdifferent periods and comportments can be distinguished: (1) Before the addition of CBZ in the MBR quite steady fouling conditions were reached, where TMP increases very slowly; (2) One day after addition of CBZ in MBR, a significant increase of TMP, a "TMP jump", was observed; (3) Between one day and eight days after addition of CBZ, TMP increased gradually while at a higher rate as compared to that before addition of CBZ; (4) Staring from eight days after addition of CBZ, a continuous TMP jump started to occur, where TMP increased at a much significantly higher rate. The sudden significant increase of $10-100 \mathrm{kDa}$ protein-like SMP one day after addition of CBZ in MBR (see figure 2) may cause a sudden loss of voids in the biocake that was formed on the MBR membrane surface and change the structure of the biocake, which could explain the sudden increase of TMP one day after addition of CBZ in MBR. The accumulation of 10-100 kDa protein-like SMPs in the biocake may result in the gradual while more rapid increase of TMP and finally caused the TMP jump. The compressing effect of biocake may also contribute to the continuous TMP jump (results not shown here).

\section{CONCLUSIONS}

In conclusion, the continuous $\mathrm{CBZ}$ pollution in $\mathrm{MBR}$ led to a significant increase of MBR fouling, which could be

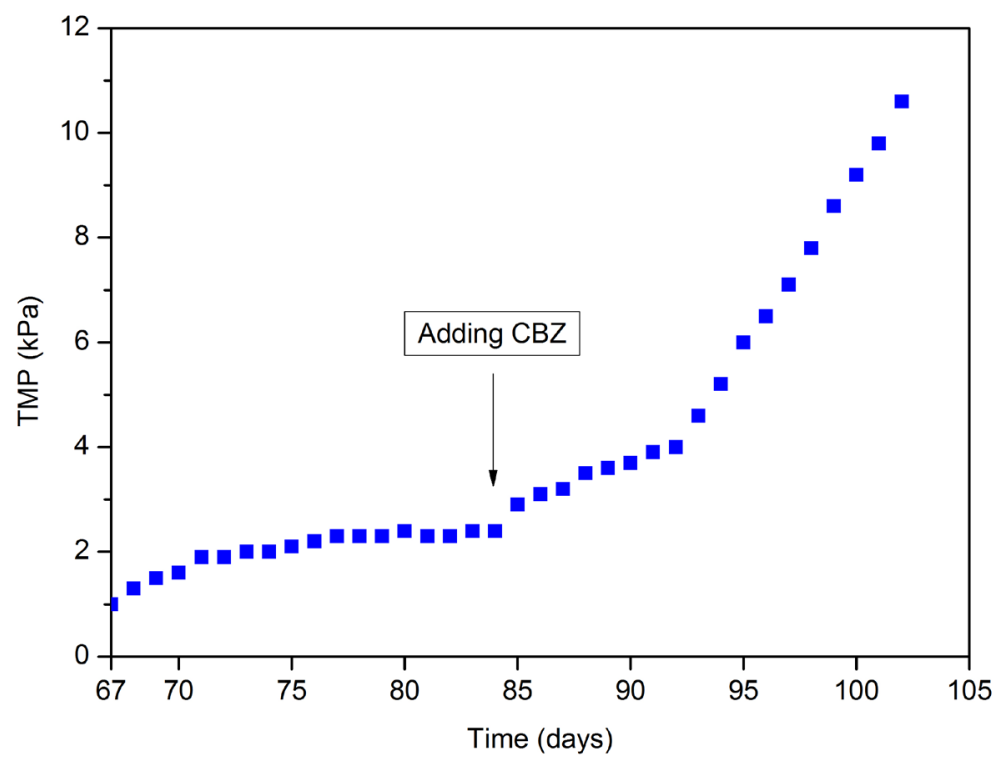

Figure 4. Effect of $\mathrm{CBZ}$ on the transmembrane pressure in the MBR $L$ 'impact de CBZ sur la pression transmembranaire du BAM 
related to the increase of $10-100 \mathrm{kDa}$ protein-like SMPs in MBR supernatant. The $10-100 \mathrm{kDa}$ protein-like SMPs could modify the structure of the biocake on membrane surface and result in internal fouling in the biocake.

\section{REFERENCES}

DAUGHTON, C.G., and T.A. TERNES (1999). Pharmaceuticals and personal care products in the environment: agents of subtle change? Environ. Health Perspect., 107, 907-938.

DREYWOOD, R. (1946). Qualitative test for carbohydrate material. Ind. Eng. Chem. Anal. Ed., 18, 499.

LAY, W.C., Q. ZHANG, J. ZHANG, D. MCDOUGALD, C. TANG, R. WANG, Y. LIU and A.G. FANE (2012). Effect of pharmaceuticals on the performance of a novel osmotic membrane bioreactor (OMBR). Separ. Sci. Technol., 47, 543-554.

SIPMA, J., B. OSUNA, N. COLLADO, H. MONCLÚS, G. FERRERO, J. COMAS and I. RODRIGUEZ-RODA (2010). Comparison of removal of pharmaceuticals in MBR and activated sludge systems. Desalination, 250, 653-659.

SMITH, P., R.I. Krohn, G. Hermanson, A. Mallia, F. Gartner, M. Provenzano, E. Fujimoto, N. Goeke, B. Olson and D. Klenk (1985). Measurement of protein using bicinchoninic acid. Anal. Biochem., 150, 76-85.

VERLICCHI, P., M. Al AUKIDY and E. ZAMBELLO (2012). Occurrence of pharmaceutical compounds in urban wastewater: Removal, mass load and environmental risk after a secondary treatment-A review. Sci. Total Environ., 429, 123-155. 